\title{
Use of Executive Orders in Nigeria by the Executive Branch of Government in Time of Emergency
}

\author{
Oluwapelumi Odunayo Osadola ${ }^{1}$, Phebe Oluwatoni Ojo ${ }^{2}$ \\ ${ }^{1}$ University of Ado Ekiti, Ekiti state, B. L, Nigeria Law School (Enugu Campus), LL. M, University of \\ Benin, Nigeria is a barrister and solicitor at Duyilemi and Partners in Port Harcourt, Nigeria \\ ${ }^{2}$ Obafemi Awolowo University, Ile-Ife, LL. B, Ajayi Crowther University, Oyo, Oyo State, Nigeria \\ Email: osadolapelumy@gmail.com, ojo@gmail.com
}

\begin{abstract}
:
Executive Orders are not invoked as a matter of course by the President or Governors heading the Executive Cabinet. These orders are exercisable when heads of the executive branch of government see for their needfulness and for smooth running of their governmental programmes or policies. Every Executive order must carry the force of law for it to be valid or to be duly recognised by the other branches of government which if not, the latter may question its constitutionality. The advantages of executive orders are very innumerable to mention however it has been said that the use of executive orders have assaulted the concept of separation of powers which is embedded in the 1999 Nigerian Constitution (as amended)as adopted from the United States of America. This paper focuses on the meaning and historical antecedent of executive orders in Nigeria, legal regime or statutory provisions of executive orders in Nigeria, executive orders versus doctrine of separation of power, challenges of executive orders under the 1999 constitution (as amended), praxis of executive orders under the Nigeria fourth republic and lastly is the conclusion and recommendations made thereto. To achieve these, the writers will make use of relevant materials at their disposal.
\end{abstract}

\section{Keywords:}

executive; legal regime; executive orders and their praxis in fourth republic

\section{Introduction}

In carrying out the functions of his office as the head of the executive branch of government, the law allows the President at the federal level or the Governors at the regional levels to make declarations, proclamations or issue directives, instructions, memoranda or orders to be carried out by the administrative agencies, departments, ministries and so on. The essence of these executive orders is to allow the president or governors as the case may be to give command that will boost their governmental policies or programmes implementable to better the life of the citizens. To achieve their numerous laudable governmental policies or programmes, the president makes use of executive powers or orders as inherently given by the constitution or statutes over the affected administrative agencies or targeted individuals as the case may be.

To Barack Obama, executive order is viewed as an administrative tools for a president like him (ex-president) to having a pen to give effect to orders and take actions (administrative actions) that will move the ball forward. ${ }^{1}$ To complement Obama's view, executive orders set out government policies, issue directives or command action relating to functions of the executive branch. An order issued by the President become rather controversial when the

${ }^{1}$ Barack Obama, "Barack Obama Citation", BrainyQuote

$<$ http://www.brainyquote.com/quotes/barack_obamasrc=t_execuitve > accessed on 26-04-2020. 
reason behindit is to make law which Nigeria as a federalist that upholds the concept of separation of powers among the three (3) branches of government limits the law making powers within the circuit of the legislature while the president is only empowered to execute laws made by the legislature. ${ }^{2}$ Moreover, the 1999 Constitution (as amended) ordinarily does not intend to make the presidency a law making body working in competition against the legislature. Some legal writers therefore view executive orders as promoters of presidential unilateralism and executive imperialism. ${ }^{3}$ In fact, supporters of the concept of separation of powers see executive orders as subverting the vitality of the constitution.

In light of the above, this paper gives a general appraisal of the topic and further focuses on the meaning and historical antecedent of executive orders in Nigeria, legal framework or statutory provisions of executive orders in Nigeria, executive orders versus doctrine of separation of power, challenges of executive orders under the 1999 constitution (as amended), praxis of executive orders under the Nigeria fourth republic and lastly is the conclusion and recommendations.

\section{Review of Literatures}

\subsection{Meaning and Historical Background of Executive Orders in Nigeria}

It is instructive to note that the term Executive Order emanated from the United States of America as far back as 1789 when George Washington was the President of the United States. Washington's first order in June 1789 directed the heads of executive departments to submit reports about their operations. Over the years, Presidents of the United States have issued Executive Orders and other actions to set holidays for federal workers, regulate civil service, designate public lands as Indian Reservations or National Parks and organize federal disaster assistance efforts among other uses. ${ }^{4}$

The expression 'Executive Order' has not been statutorily or constitutionally defined in so far as Nigeria is concerned. In fact, the expression is not defined in the Constitution neither has it been interpreted in any legislation of the National Assembly or House of Assembly of any state of the federation. Also, the few Acts of the legislature that contain the expression 'executive order' do not define or interpret it. The Interpretation Act also does not have any definition of the expression. It is therefore safe to turn to the United States of America where the use of executive order is predominant for the several definitions of the term. ${ }^{5}$

According to the Black's Law Dictionary (seventh edition), executive order is defined 'as an order issued by or on behalf of the president intended to direct or instruct the actions of executive agencies or government officials, or to set policies for the executive branch to follow. ${ }^{16}$

${ }^{2}$ R. Morton "Beyond the Limits of Executive Power: Presidential Control of Agency Rulemaking under Executive Order 12,291" Michigan Law Review 80, (1981): 193-247 where it is observed that the framers of the Constitution of the USA did not intend the presidency to be an institutional competitor to the Congress. ${ }^{3}$ Elijah O. Okebukola and Abdulkarim A. Kana, "Executive Orders in Nigeria as Valid Legislative Instruments and Administrative Tools", NAUJILJ, 66 (2012), C. S. Kelley "Executive Orders and the Modern Presidency: Legislating from the Oval Office by Adam L. Warber (Review)" Presidential Studies Quarterly 37 (2007): 169-170 at 169.

4"Executive Order" (2018) History.com Editors <https://www.history.com/topics/us-government/executiveorder> accessed 21-04-2020

${ }^{5}$ E.O Okebukola and A.A Kana, "Executive Orders in Nigeria as Valid Legislative Instruments ", above note 4 ${ }^{6}$ Black's Law Dictionary, 7 th Edition 
The Nolo's Plain English Law Dictionary defined executive order 'as a declaration by the president or governor which has the force of law, usually based on existing statutory powers and requiring no action by the congress or state legislature. ${ }^{17}$

The American Bar Association also stated that an Executive Order 'is a signed, written and published directive from the president of the United States that manages operations of the federal government. They are numbered consecutively, so executive orders may be referenced by their assigned number, or their topic. ${ }^{8}$

According to Meyer, Executive Order is a presidential directive that requires or authorizes some action within the executive branch. ${ }^{9}$ Raven-Hansen also posits that executive orders are presidential policy directives to the federal bureaucracy. ${ }^{10}$

Okebukola and Kana define executive order as a command directly given by the president to an executive agency, class of persons or body under the executive arm of government. ${ }^{11}$ The authors went further to state that such a command is in furtherance of government policy or Act of the legislature. The executive order may require the implementation of an action, set out parameters for carrying out specific duties, define the scope of existing legislation or be a subsidiary instrument within the contemplation of section 37 of the Interpretation Act. ${ }^{12}$

It can therefore be deduced that executive powers are presidential directives or pronouncements made pursuant to existing statutory powers which sets out policies and plans for the executive agencies and which requires compliance.

\subsection{Legal Framework of Executive Order}

A key element of an Executive Order is that it carries the force of law which also lies the challenge to its constitutionality. ${ }^{13}$ It is no doubt that the Constitution clearly demarcates the powers among the three arms of government- the Legislature, Executive and the Judiciary as provided in Sections 4, 5 and 6 respectively of the 1999 Constitution of the Federal Republic of Nigeria (as amended). This separation of powers is to prevent abuse and tyranny by one individual or one arm of government. ${ }^{14}$

It is however important to note that while Legislative and Judicial powers are vested in institutions, Executive Powers are vested in the President and may be exercised by him directly or through the Vice President and Ministers of the Government of the Federation. ${ }^{15}$ The Constitution also states explicitly the scope and purpose of executive power, which is for 'the execution and maintenance of the Constitution, all laws made by the National Assembly

\footnotetext{
${ }^{7}$ 'Executive Order', Cornell Law School < www.law.cornell.edu/wex/executive_order> accessed 17th April, 2020

8"What is an Executive Order" (2018) ABA Journals

$<$ https://www.americanbar.org/groups/public_education/publications/teachings-legal-docs/what-is-anexecutive-order-/ > accessed 17-04-2020

9 K.R Meyer, "Executive Orders and Presidential Powers" The Journal of Politics 445-466 (1999): 61

${ }^{10} \mathrm{P}$. Raven-Hansen, "Making Agencies Follow Orders: Judicial Review of Agency Violation of Executive Order"

Duke Law Journal (1983):285-253

11 Above note 4

12 Ibid

13 Funmilayo Odude, “Assessing the Legality of Executive Orders" (2018)

https://www.financialnigeria.com/assessing-the-legality-of-executive-orders-blog-338.html accessed 19-04- 2020 ${ }^{14} \mathrm{Ibid}$

15 Constitution of the Federal Republic of Nigeria, 1999 (as amended), section 5(1)(a)
} 
and to all matters with respect to which the National Assembly has for the time being power to make laws. ${ }^{16}$

Executive Orders are products of the exercise of presidential power under the Constitution. They have legal force when they are based on the President's Constitutional or Statutory authority. They are valid only where Presidents act within the boundaries of their Constitutional Authority. ${ }^{17}$ The enabling Constitutional or Legislative authority may empower the President to use Executive Order to perform strictly defined roles. Pursuant to Section 2(2) of the Advisory Council on Religious Affairs Act Cap A8 Laws of the Federation of Nigeria, 2004, the President may vary increase or reduce the membership of the council by an order published in the Federal Gazette. ${ }^{18}$ Similarly, section 33 of the Firearms Act also empowers the President to consult with the National Council of Ministers before making regulations covering a wide range of issues relating to Firearms. Section 134(2) of the Custom and Excise Management Act empowers the President to, by Order, amend the second schedule to the Act. Section 5(2) of the International Financial Organization also mandates the President to order, make such provisions of the agreements relating to the International Monetary Fund, the International Bank for Reconciliation and Development, the International Finance Corporation and the International Development Association. These are some of the Statutory Provisions that empowers the President to make Orders akin to laws. The power conferred on the President is explicitly spelled out. ${ }^{19}$ However, where the enabling law sets limits to the President's powers, any executive order outside the express instructions of the legislature will be made null and void. That is where the legislature stipulates that the president may issue a specific order, then it is left to the absolute discretion of the president to issue that order not otherwise.

Also, the legislature or constitution may confer wide discretionary power on the president to issue orders in certain matters, such as declaring a state of emergency in turbulent times. This is demonstrated by the 1999 Constitution which allows the President and other appropriate authority consider necessary to bring that law into conformity with the provisions of the Constitution. This is provided in Section 315(2) of the 1999 Constitution of the Federal Republic of Nigeria (as amended). The other appropriate authorities are the Governor of States and any person appointed by any law to revise and rewrite the laws of the Federation or of a State. The President is given the discretion to first determine if some aspects of an Act that precedes the 1999 Constitution are inconsistent with the Constitution, such as military decrees that are yet to be repealed. ${ }^{20}$ This is provided in Section 315(1) (a) of the 1999 Constitution of the Federal Republic of Nigeria (as amended). Thereafter, the President has the discretion to amend the text of the law in such a manner that will align the Act with the Constitution. Thus, in the case of Attorney-General of Abia State .v. Attorney-General of Federation, ${ }^{21}$ the Supreme Court stated that the two tests for determining the constitutionality of an existing law are: whether the modification orders brings the relevant Act into conformity with the provisions of the Constitution, and whether there has been an infraction of the Constitution by the Order.

It can therefore be said that the concept of executive order is not totally strange to our jurisdiction as they are embedded in our Statutory Provisions of which the President can

\footnotetext{
16 Constitution of the Federal Republic of Nigeria, 1999 (as amended), section 5(1)(b)

17 Okebukola and Kana, "Executive Orders in Nigeria" above note 4

18 Ibid.

19 Funmilayo Odude, "Assessing the Legality of Executive Orders" above note 14

${ }^{20}$ Okebukola and Kana, "Executive Orders in Nigeria" above note 4

21 [2003] 4NWLR (PT 809) P.124 at 177 para F
} 
choose to utilize or otherwise. The crux of this is that all Executive Orders must derive their validity from the Constitution or from Acts of the National Assembly as well as Laws made by the State House of Assembly as the case may be. Anything that falls short of this will be considered null and void.

\section{Discussion}

\subsection{Executive Orders versus Doctrine of Separation of Powers}

The definition of Executive Order as rules issued by the president that have legal effect raises issues about the nature of Executive Orders. Executive Order have the force of law. This raises problem for the rule of law in a polity. The rule of law both from a Constitutional and Administrative Law conception implies the separation of power. ${ }^{22}$

As Montesquieu rightly observed centuries ago, the only way to guarantee the liberty and freedom of the people is to ensure that power is not concentrated in one person or organ. If the entire power is concentrated in one person, then there is a strong possibility of abuse and tyranny. ${ }^{23}$ The Nigerian Constitution has given an elaborate expression to this fundamental idea by separating the Legislative, Executive and Judicial powers and vesting each on these three different organs whose personnel should not be intermingled. This strict separation is moderated by checks and balances that allows different branches of government to support one another for effective administration. ${ }^{24}$

Generally, fundamentally the law making function is clearly defined as the responsibility of the Legislature. However, this power must be exercised by both legislative house and signed by the President. ${ }^{25}$ Where this process is not strictly followed, the Supreme Court has held such exercise as unconstitutional. This was demonstrated in the case of Attorney-General of Bendel State .v. Attorney-General of the Federation and orders ${ }^{26}$ where the supreme court nullified a purported passage of Appropriation Act by a committee of the National Assembly without a concurrent vote of two-third of members of the Senate and House of Representative. If Executive Orders have the force of law, it means that the President makes law by issuing Executive Orders. This circumvents the clear processes of law making in the Constitution. It vests on the President additional power that tilts the delicate balance in the power dynamics of a constitutional democracy, especially one with a written constitution. ${ }^{27}$

It is important to bear in mind that even as Section $5(1)(b)^{28}$ grants the president wide power to maintain the Constitution and the laws and to attend to all matters which the National Assembly has power to make law, the preamble to Section $5^{29}$ limits the exercise of this wide power. The executive power of the federation that vests on the President is to be exercised subject to the provisions of the Constitution and to the provisions of any other law made by the National Assembly. This suggests that the president can exercise this power of his office only in accordance with provisions of the Constitution and laws made by the National Assembly. The President cannot act in the interest of justice by violating the

\footnotetext{
22 Sam Amadi, "Executive Order and Presidential Power in the Nigerian Constitutional Democracy" The Guardian Newspaper (October 17 2018) <https://www.google.com/amp/s/guardian.ng/features/executive-orderand-presidential-power-in-the-nigerian-constitutional-democracy/?espv=1 accessed 22nd April, 2020

23 Ibid

${ }^{24}$ Ibid

25 Ibid

26 (1983) ALL NLR 208

27 Sam Amadi, "Executive Order and Presidential Power in Nigerian Constitutional Democracy" above note 23

28 Constitution of the Federal Republic of Nigeria, 1999 (as amended)

29 Constitution of the Federal Republic of Nigeria, 1999 (as amended)
} 
provisions of the Constitution and Laws made by the National Assembly. He can only take actions which are in consonance with the provisions of the Constitution and Acts made by the National Assembly. ${ }^{30}$

It is therefore the writer's view that executive order will not inhibit the doctrine of separation of powers as long as such orders are made in consonance with the provisions of the Constitution and Laws made by the National Assembly. However, where such order (s) conflict with the Constitution and Laws made by the National Assembly, such order will be declared null and void when challenged before a competent court.

\subsection{Challenges of Executive Orders under the 1999 Constitution (As Amended)}

In carrying out the function of the office, the President in a presidential system such as Nigeria and the United States may issue orders to agents and agencies of the executive branch. These orders may set out government policies, issue directives or command action relating to functions of the executive arm. However, in the exercise of these orders, one may realize that the President or Governors as the case overstep certain bounds and that might bring about executive unilateralism or presidential imperialism. Having said that, the challenges posed by the use or misuse of executive orders include but not limited to the factors listed hereunder:

\section{Frequent Friction}

Barber wrote that 'where institutions are straining against each other, set in tension rather than comity. ${ }^{31}$ In that regard, where the executive order to be exercised does not have any constitutional backing or is not in conformance with the constitution, then it may bring about friction between the executive and the legislature. For instance, tension might arise where the legislative arm alleges that an executive order is inconsistent with an existing act of the national assembly. ${ }^{32}$ Ordinarily, such an inconsistent order will be adjudged void to the extent of the inconsistency. Invalidity of such an order is however not so clear-cut where the President claims to be acting pursuant to the Constitution and that the Act in issue "has sought to limit the constitutional provision invoked as authority. ${ }^{, 33}$

2. Unhealthy rivalry between institutional mechanisms of Government:

According to Mommsen 34 , "that generally constitution always provides for a President and parliament, each within autonomous source of legitimacy." From this expression, it is very possible for both arms to compete for constitutional powers most especially when the President or Governors is issuing an order in law making manners. Similarly, there have been occasions where the Legislature has challenged executive orders over time. In the USA for example, 'between 1973 and 1997, Congress challenged only 36 of more than 1,000 executive

\footnotetext{
30 Sam Amadi, "Executive Order and Presidential Power in Nigerian Constitutional Democracy", above note 23 ${ }^{31}$ N.W. Barber "Self- Defence for Institutions" the Cambridge Law Journal 72, 3(2013):570 - 574

${ }^{32}$ Elijah O. Okebukola and Abdulkarim A. Kana, "Executive Orders in Nigeria as Valid Legislative Instrument", above note 4

${ }^{34}$ G L Bliley "Government by Executive Order" (1934) 82 University of Pennsylvania Law Review and American Law Register $739-747$ at 741.

${ }^{34}$ W. J. Mommsen Max Weber and German Politics, 1890-1920, Michael S. Steinburg (trans.) (Chicago: University of Chicago Press, 1985)
} 
orders issued. ${ }^{35}$ And only two of these 36 challenges led to overturning the President's executive order. ${ }^{36}$

\section{Disaffection:}

It is capable of causing disaffection among the three arms of government where the scope or extent of the Orders are neither clearly defined nor the explicit powers of the issuing authority- the President or Governor conferred by legislation. Thus, altering the structure of the constitution which recognises the separation of powers among the three arms without one overlapping on the duty of the other. But a better understanding of the nature of an Executive Order enforces the importance of collaboration amongst the three organs of government is capable of preventing such feelings of disaffection.

\section{May breed Executive Dictatorship:}

Here, the constitutional framework of over concentrating of governmental powers in the executive President can corrupt him and make him to be a dictator without any control from the other two branches of government. ${ }^{37}$ As it was imperative that one branch of government be responsible for creating the laws while another carry the responsibility for executing them. ${ }^{38}$ Separating these tasks was viewed as necessary to protect the "public security' and to prevent arbitrary and tyrannical rule. ${ }^{39}$

\section{Causes divided Government:}

This arises where the president does not enjoy the sympathy of the cabinet majority that will support his government to achieve its laudable governmental programmes such as any policy-formulations geared towards promoting robust and economy-driven society.

\section{Vulnerable to Constitutional Democratic Breakdown:}

In principle, sovereignty in Nigeria's constitutional democracy resides in the people. ${ }^{40}$ As noted in Fawehinmi $v$ Babangida, ${ }^{41}$ the supremacy of the constitution is the hallmark of constitutional democratic governance because it is a reflection of the powers granted by the people to meet their aspirations. In Bubariv Obasanjo, ${ }^{42}$ the Court stated that the Constitution is a general statement of how Nigerians wish to be governed. Thus, where an executive order will affect the rights of citizens, the order will be invalid if not unconstitutional, whimsical or capricious and if not curtailed by courts may bring about constitutional breakdown.

\subsection{Praxis of Executive Orders under the Nigerian Fourth Republic}

Okebukola and $\mathrm{Kana}^{43}$ have observed that the expression of presidential authority through the use of executive orders necessarily occurs in a political and institutional context. Thus, in framing and issuing executive orders, the President considers the reaction of

${ }^{36} \mathrm{G}$ A Krause and J E Cohen "Opportunity, Constraints, and the Development of the Institutional Presidency: The Issuance of Executive Orders, 1939-96” (2000) 62: The Journal of Politics 88-114 at 95. However, from 1997 to February, 2020, Congress has challenged executive orders once in 2014 out of over 863 executive orders issued from Clinton's administration to Trump's government. See Deirdre Walsh, "GOP-led House authorizes lawsuit against Obama." <CNN.com, July 30, $2014>$ accessed on 20-04-2020.

${ }^{37}$ Ibid, p. 95. Unlike Nigeria, where the courts hardly invalidate on presidential executive orders so far they are consistent with the constitution and therefore rendered valid. See A.-G., Abia v A.-G., Federation [2003] 4 NWLR (Pt. 809) p. 124 at 177 para. F.

${ }^{37}$ Cindy Skach, "Constitutional Origins of Dictatorship and Democracy," Const. Pol. Econ.16, 347 (2005)

${ }^{38}$ THE FEDERALIST No. 47, at 336 (James Madison) (Benjamin Fletcher Wright ed.,1996).

${ }^{39}$ THE FEDERALIST No. 77, at 489 (Alexander Hamilton) (Benjamin Fletcher Wright ed., 1996).

${ }^{40}$ See S. 14(2) (a),Constitution of the Federal Republic of Nigeria, 1999 (as Amended)

${ }^{41}$ Fawehinmi v Babangida [2003] 3 NWLR (Pt. 808) p. 604 at 651 paras. F-G.

${ }^{42}$ Buhari v Obasanjo [2003] 17 NWLR (Pt 850) p. 587 at 635 para G.

${ }^{43}$ Okebukola and Kana, "Executive Orders in Nigeria", above note 4 
opponents, its implement ability and costs or benefits of relying on alternative tools of command such as legislation or court orders. Notwithstanding the political and policy issues the President takes into consideration, 'executive orders have legal force only when they are based on the President's constitutional or statutory authority.' They are valid only where Presidents act 'within the boundaries of their constitutional or statutory authority." ${ }^{44}$

Throughout the Fourth Republic, Nigeria has witnessed crude politicking and violations of executive powers and most unfortunate part is that this misuse of executive power is still rampant in President Buhari's current Administration who was once a political victim under the Obasanjo government and which one would think his government will greatly frown at it but only to see the proliferation and continuation of neo militarism and executive imperialism of use of executive orders under the disguise of constitutional validity. Besides the judicial flavours given to some executive orders issued by past presidents before the incumbent administration, this administration has issued over ten (10) executive orders from the inception of his tenure since 2015 to the present date.

Herewith are those executive orders validated by courts as issued by President Buhari's administration to wit: one, executive order (EO1) on the Promotion of Transparency and Efficiency in the Business Environment; two, executive order EO2 on Budgets; three, executive order (EO3) on support for Local Content in Public Procurement by the Federal Government; fourth, executive order (EO4) on the establishment of the voluntary Assets and income Declaration Scheme (VAIDS); fifth, executive order (EO5) on Planning and Execution of Projects, Promotion of Nigerian Content in Contracts and Science, Engineering and Technology; sixth, executive order (EO6) on the preservation of Assets Connected with Serious Corruption and other Related Offences, seventh, executive order (EO7) on the Companies Income Tax (Road Infrastructure Development and Refurbishment Investment Tax Credit Scheme ${ }^{45}$, eighth, executive order (EO8) on Voluntary Offshore Assets Regularization Scheme ${ }^{46}$, nineth, executive order (EO9) on the Open Defecation- Free Nigeria by $2025^{47}$ and lastly the tenth one is executive order (EO10) on financial autonomy to thirty six (36) states' Houses of Assembly and the judiciary. ${ }^{48}$ As laudable these executive orders might have been, the news of their signing at one or the other has greeted with either public outcry at worst or with mass apathy at best. ${ }^{49}$ For instance, the three executive orders VI, VII and X issued and signed in October, 2018, November, 2019 and May, 2020 respectively have not left without serious criticisms.

For the former, most critics believe that President Buhari took this position in the assumption that all the assets are mostly illegally acquired even before the courts have the

\footnotetext{
${ }^{44}$ R. Brandon and M. Jason, "The Power of Decree: Presidential Use of Executive Proclamations, 1977-2005” (2007) 60 Political Research Quarterly 338-343 at 339.

${ }^{46}$ Jonathan Ekpo, "A Critique of the Companies Income Tax (Road Infrastructure Development and

Refurbishment Investment Tax Credit Scheme) Order 2018” Odujinrin \& Adefulu Solicitors estd. 1972: 2019> accessed on 18-04- 2020

${ }^{46}$ His Excellency, President Muhammadu Buhari, GCFR, on $8^{\text {th }}$ October 2018 signed Executive Order No. 008 ("the Order") authorizing the Attorney-General of the Federation and Minister of Justice to set up a Voluntary Offshore Assets Regularization Scheme in Switzerland (VOARS or "the Scheme"). See home.kpmg/ng/en/home/insights/2018/10/Executive-Order-008-on- Voluntary- Offshore-AssetsRegularization-Scheme.html > accessed on 14-09-2020

${ }^{47}$ Femi Adesina, "President Buhari signs Executive Order 009 on the Open Defecation- Free Nigeria by 2025", Press statement released on $20^{\text {th }}$ November, 2019. See https://waterresources.gov.ng/2019/11/21/presidentbuhari-signs-executive-order-009-on-the-open-defecation-free-nigeria-by-2025/> accessed on 14-09-2020 48 Jideofor Adibe, "Reflections on Buhari's Executive Order No. 10", Daily Trust May 22, 2020. See https:// daily trust.com/ reflections-on-buhari's-executive-order-no-10 $>$ accessed on 14-09-2020

${ }^{49}$ Ibid. p. 1
} 
opportunity to determine that. Further to the above, some legal analysts are of the view that the power to determine which assets should be subject to temporary or final confiscation is a judicial power vested in the Courts by Section 6 of the 1999 constitution, for the determination of the civil rights and obligations of the citizens. ${ }^{50}$ Whilst on the seventh executive order, many legal scholars of the doctrine of separation of power have posited that this executive order usurps the powers of the legislative arm of government in a democratic setting like ours, ${ }^{51}$ and on the tenth executive order, several legal writers have opposed it on the premise that the President's order on financial autonomy for each state house of assembly and the judiciary is a constitutional issue which can only be constitutionally resolved by the national assembly through constitutional amendment and not by mere executive order by the president. $^{52}$

Notwithstanding the above criticisms and the challenge of the validity of the Executive Order VI before a Federal High Court, the court dismissed the suit for lacking in merit and affirmed that the president has the constitutional powers to issue the Executive Order as long as it does not encroach into the principles of separation of powers. It further ruled that the Executive Order was issued as a policy directive for the implementation of provisions of existing laws and that it recognized the right of every citizen to approach the court for redress if aggrieved by enforcement of the executive order. ${ }^{53}$

Conclusively, the recent presidential directives and several Governors' orders of various states of the federation made on containment of the global disease of Corona virus in line with the Quarantine Act and other related regulations thereto and its legal implications on the socio economic, political, health and fundamental rights of the citizens can never be glossed over as the deaths of citizens resulted from human rights abuses alone as a result of these presidential directives or executive orders are on the rise across the states of the federation daily with little or no effort to curtail it by the government. ${ }^{54}$

\section{Conclusion}

Undoubtedly to say that policy-making by presidents have grown greatly under the incumbent Buhari's Administration just like the way it grew in American modern days' politics. One fact that cannot be shirked about the use of executive orders is that it runs in opposite to the concept of separation of powers as encapsulated in the 1999 Nigerian Constitution (As Amended) which demarcates power sharing among the three branches of government except that one branch may serve as a watch dog to the other branches vice versa. No wonder, Madison vehemently posited that the use of executive powers amounts to an ambitious encroachments of the executive branch against the other branches of government which may raise signal for general alarm or plan for concerted resistance. ${ }^{55}$

\footnotetext{
${ }^{50}$ Stella Ovie, "The Executive Powers of the President" , Kusamotu and Kosamotu Solicitors> accessed on 20-04-2020

51 Ibid. p. 5

52 Above note, 49

${ }^{53}$ Ibid. p. 10

${ }^{54}$ Amnesty International 2020, "Nigeria: Authorities must uphold human rights in fight to curb COVID-19", published on 1st April, $2020>$ accessed on 22-04-2020 at <http://www.amnesty.org>; AL, JAZEERA AND NEWS AGENCIES 2020, "Nigerian Security Forces Kill 18 During Curfew Enforcement" published on $16^{\text {th }}$ April, 2020> accessed on 22-04-2020 at <http://aljazeera.com>

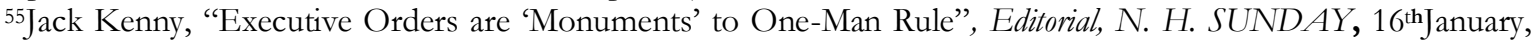
2000.> accessed on 26-04-2020("along history of abuse of power hardly justifies its continuance .... It was, after all, against 'a long train of abuses and usurpations' that the colonists issued their Declaration of Independence."); Tara L. Branum, "President or King - The Use and Abuse of Executive Orders in Modern-Day America," Journal of Legislation, vol. 28: Iss. 1, Art. 1 : (2002) Available at: http://scholarship.law.nd.edu/jleg/vol28/iss1/1
} 
It is on this premise that courts and Congress have made temporal attempts to oppose to the use of executive powers more particularly in law-making patterns which they see as an assault and usurpation of constitutional powers of the latter to make law. To what extent those several criticisms have prevailed over the use of executive orders remain in abeyance as case laws relating to matters bothering on executive orders have shown that courts validated virtually if not all the executive orders issued by the presidents under the fourth republic as long as those orders are made pursuant to the force of law or received constitutional backing. As controversies surrounding the use of executive orders lingers on, it is important to know that the incumbent government has made tremendous success through the use of executive orders to drive home some of their governmental programmes and policies to arrest critical situations our country found herself in. Most recent is the use of executive orders by government at respective levels to combat the global pandemic of corona virus currently raving the globe inclusive Nigeria. However, it is also disgusting to know that the reprehensible effect of the use of executive orders in Nigeria most especially when orders are issued to become laws or without due process duly observed ${ }^{56}$; this brings about the unhealthy competitions among the three branches of government which remain the main challenge and/or other challenges posed by the use of executive orders.

To prevent these problems, there is an urgent need for proper records, accountability and transparency in trans-government implementation of the use of executive orders by the president or governors. And to achieve this, the legislature must consider the enactment of a law that will require for periodic collection, collation and publication of all executive orders as it is reflectively done in United States of America. ${ }^{57}$

${ }^{56}$ C. Ukpong "Buhari Speaks on Arrest of Judges; Says Corruption, Not Judiciary under Attack", Premium Time Headlines,(2016); Amadi, "Executive Order and Presidential Power" above note 23

57 Above note 4 